\title{
ウロキナーゼ固定化フェモラールカテーテル留置中の 凝固線溶系の変化
}

\author{
北本 康則福井博 義* 出口隆志** 松下 和 孝*** \\ 桑原邦治中山真人 佐藤 辰男
}

熊本大学第 3 内科 熊本中央病院腎臓内科* 八代総合病院腎センター** あけぼのクリニック*** (昭和 63 年 11 月 16 日受付)

key words : femoral vein catheter, urokinase immobilization, coagulation, fibrinolysis

〈要旨〉

ウロキナーゼ固定化フェモラールカテーテルを 9 名（男 5, 女 4 ）の維持透析患者に留置した。留置後 3 回の血液 透析を行ない, その間のプラスミノーゲン, フィブリノーゲン, フィブリノペプタイド A (FPA), フィブリノペプタ イド B $\beta$ 15-42 (FPB $\beta$ ), フィブロネクチン, von Willebrand 因子 (VWF : Ag, RCoF) の血中濃度を測定した。留置 後第 1 回目の透析前後で, プラスミノーゲンは $81.4 \pm 29.0 \%$ から $87.6 \pm 23.5 \%$ 、フ フィブリノーゲンは $397.4 \pm 74$. $7 \mathrm{mg} / \mathrm{d} /$ から $399.0 \pm 51.9 \mathrm{mg} / \mathrm{d} /$ へ, FPA は $18.9 \pm 31.4 \mathrm{ng} / \mathrm{m} /$ から $9.7 \pm 18.7 \mathrm{ng} / \mathrm{m} /$ へ, FPB $\beta$ は $52.1 \pm 13$. $3 \mathrm{ng} / \mathrm{m} /$ から $45.8 \pm 13.2 \mathrm{ng} / \mathrm{m} /$ へ変化したものの, いずれも統計的に有意差は認められなかった. つづく 2 回の透

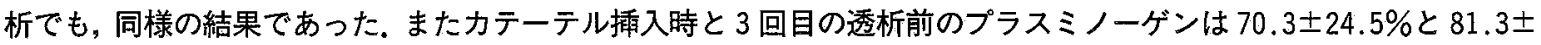
$25.4 \%$ で, フィブリノーゲンは $355.4 \pm 102.5 \mathrm{mg} / \mathrm{d} l$ と $404.1 \pm 83.6 \mathrm{mg} / \mathrm{d} l$, フィブロネクチンは $177.0 \pm 99.3 \mu \mathrm{g} /$ $\mathrm{m} /$ と $230.8 \pm 52.0 \mu \mathrm{g} / \mathrm{m} / \mathrm{FPA}$ は $18.9 \pm 31.4 \mathrm{ng} / \mathrm{m} /$ と $25.9 \pm 27.6 \mathrm{ng} / \mathrm{m} /, \mathrm{FPB} \beta$ は $52.1 \pm 13.3 \mathrm{ng} / \mathrm{m} /$ と $59.0 \pm$ $17.4 \mathrm{ng} / \mathrm{m} /$ であり，いずれも有意差は認めなかった。ただし $\mathrm{vWF}: \mathrm{Ag}$ および RCoF はカテーテル留置中, 持続的 に高值を示した。

ウロキナーゼ固定化フェモラールカテーテル留置による線溶系の元進は，全身の凝固線溶系に乱れを生じさせない 程度のものであると考えられた。

\section{Changes in serum clotting and fibrinolytic proteins during hemodialysis using a urokinase immobilized femoral vein catheter}

Yasunori Kitamoto, M. D., Hiroyoshi Fukui, M. D.*, Takashi Deguchi, M. D.**, Kazutaka Matsushita, M. D.***, Kuniharu Kuwahara, M. D., Mahito Nakayama, M. D., Tatsuo Sato, M. D.

3rd Department of Internal Medicine, Kumamoto University Medical School ; Kumamoto Chuo Hospital* ; Yatsushiro Sogo Hospital** ; Akebono Clinic***

Indwelling urokinase immobilized femoral vein catheters were positioned in 9 chronic hemodialysis patients. Serum concentrations of plasminogen, fibrinogen, fibrinopeptide A, fibrinopeptide B $\beta 15-42$, fibronectin and von Willebrand factor ( $V W F: A g$ and RCoF) were measured before and after the first 3 hemodialyses. None of the concentrations of plasminogen, fibrinogen, fibrinopeptide $A$ and fibrinopeptide $B \beta 15-42$ had changed significantly after each of 3 hemodialyses. Moreover, the concentrations of plasminogen, fibrinogen, fibrinopeptide $A$, fibrinopeptide $B \beta 15-42$ and fibronectin fluctuated during the period the catheter was left indwelling without showing any definite tendencies. Concentrations of VWF remained high throughout the period of catheterization.

Urokinase immobilized catheters indwelling in femoral veins had no significant effect on systemic clotting or fibrinolysis.

北本 康則 熊本大学第 3 内科

干 860 熊本市本荘 1-1-1（096-344-2111）
緒言

近年，医療材料住抗血栓性を付与する目的で種々の工 
表 1 ウロキナーゼ固定化フェモラールカテーテルを 留置した症例

\begin{tabular}{|c|c|c|c|c|c|}
\hline & 症例 & 性别 & 年齢 & 原疾患 & カテーテル留置理由 \\
\hline 1 & & M & 55 & 糖尿病 & 透析導入 \\
\hline 2 & & $\mathrm{M}$ & 57 & 糖尿病 & 透析導入 \\
\hline 3 & & F & 70 & 良性腎硬化症 & 透析導入 \\
\hline 4 & & $\mathrm{~F}$ & 50 & 慢性腎炎 & 透析導入 \\
\hline 5 & & F & 49 & 不詳 & 透析導入 \\
\hline 6 & & M & 69 & 慢性腎炎 & シャント再建 \\
\hline 7 & & M & 62 & 不詳 & 透析導入 \\
\hline 8 & & $\mathrm{~F}$ & 77 & 不詳 & 透析導入 \\
\hline 9 & & M & 61 & 糖尿病 & 透析導入 \\
\hline
\end{tabular}

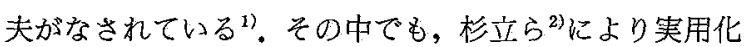
されたウロキナーゼ固定化材質は，優れた抗血栓性を有 している，我々も，ウロキナーゼ固定化ポリウレタンを 用いたブラッドアクセスであるカテーテル (UKFC) を 開発し，その有用性について既に報告して来た ${ }^{3 \sim 6)}$. 固定 化ウロキナーゼは，血液中のプラスミノーゲンをプラス ミンに転換して線溶を充進するが，この線溶兄進は局所 性であると考光られる。

今回我々は，これらカテーテル留置症例に括ける末梢 血の凝固線溶系因子の変化を測定し，カテーテル留置が 全身の凝固線溶系に及济す影響を検討したので報告す る.

\section{対象と方法}

維持透析患者 9 例 (男 5 , 女 4 例，平均年齢は $61.1 \pm$ 9.5 歳), 原疾患汸糖尿病 3 例, 慢性腎炎 2 例, 良性腎硬 化症 1 例，不詳 3 例であった(表 1 )。 カカテーテル留置を 必要とした理由は，透析導入が 8 例，シャント閉塞が 1 例であった。

カテーテルはウロキナーゼ固定化フェモラールカテー テル（ユニチカ社製）を用いた。透析終了時にはウロキ ナーゼ固定化内栓を充填し，次回に備えた，固定化ウ口 キナーゼ活性はカテーテルが $10 \mathrm{IU} / \mathrm{cm}^{2}$, 内栓が $6 \mathrm{IU} /$ $\mathrm{cm}^{2}$ であった。カテーテル留置は透析直前とし，留置後 3 回の透析時に採血を行なった。透析はホローファイ バー型ダイアライザーを用い，血流量 120-180 ml/分, 透析液流量 $500 \mathrm{~m} l /$ 分で，全身へパリン化法にて $3 \sim 5$ 時間施行した。除水量は 1 回の透析につき $1.5 \mathrm{~kg}$ 以内て あった，透析時の凝固トラブルはなく，透析中の輪血も 行わなかった。

この間，フィブリノペプタイド A (FPA) フィブリノ ペプタイド $\mathrm{B} \beta 15-42(\mathrm{FPB} \beta)$ は, radioimmuno assay により測定し,フィブリノーゲンは凝血法,プラスミノー ゲンは合成基質法, フィブロネクチンは免疫拡散法, von Willebrand 因子抗原 (vWF : Ag) は enzyme linked

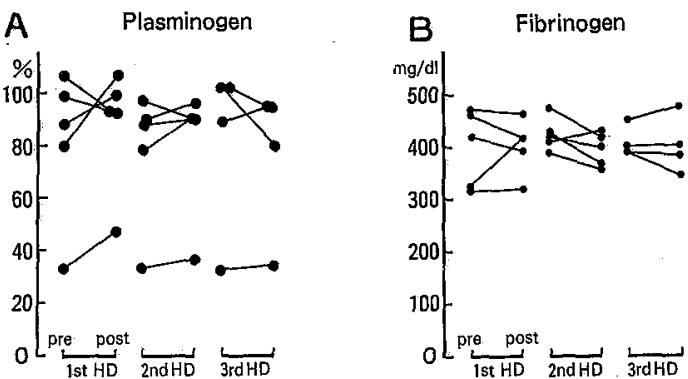

図 1 カテーテル留置中の透析前後での plasminogen fibrinogen 血中濃度の変化

A
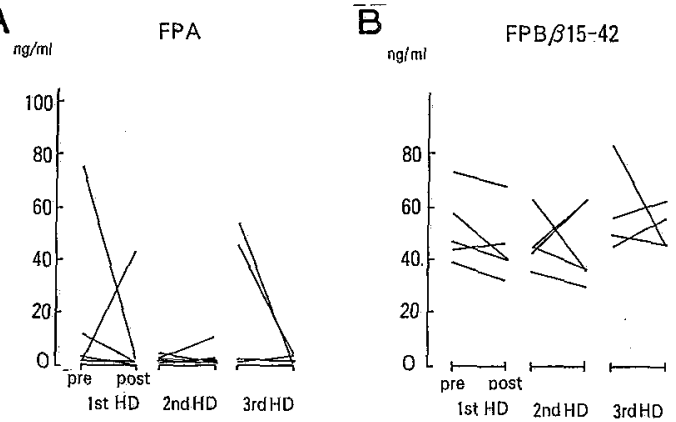

図 2 カテーテル留置中の透析前後での FPA, $\mathrm{FPB} \beta$ 15-42 血中濃度の変化

immunosorbent assay, またリストセチンコファクター 活性 $(\mathrm{RCoF})$ は血小板凝集法を用いて測定した。有意差 判定には $\mathrm{t}$ 検定を用いた。

\section{結果}

プラスミノーゲンとフィブリノーゲンの透析前後での 血中濃度の変化を図 1 に示した。プラスミノーグンは, 1 回目の透析で 3 例で増加，2例で減少した（図 $1 \mathrm{~A}$ ）。 5 例の透析前の平均が $81.4 \pm 29.0 \%$, 後が $87.6 \pm 23.5 \%$ であった。 2 回目の透析では，プラスミノーダンは 4 例 で増加， 1 例で減少した。透析前の 5 例の平均值は $77.2 \pm 25.6 \%$ ，後は 80.6土25.1\%であった。 3 回目の透 析では 2 例で増加，2 例で減少した。透析前の 4 例の平 均值が $81.3 \pm 33.4 \%$, 後が $75.8 \pm 28.7 \%$ あった。. 3 回 の透析すべてにつき，透析前後でのプラスミノーゲン濃 度の変化は有意ではなかった。

血中フィブリノーグン濃度は，1回目の透析前後で2 例に増加，3例に減少をみた(図 1 B)，5例の透析前の フィブリノーゲン濃度の平均は $397.4 \pm 74.7 \mathrm{mg} / \mathrm{d} l$, 後の 平均は $399.0 \pm 51.9 \mathrm{mg} / \mathrm{d} l$ であった。 2 回目の透析では 1 例で増加， 4 例で減少した。透析前 5 例の平均は 423 . $0 \pm 30.4 \mathrm{mg} / \mathrm{d} l$, 後は $393.6 \pm 31.6 \mathrm{mg} / \mathrm{d} l$ となった. 3 回 目の透析では，1例で増加，2例で減少，1例で不変て 
A

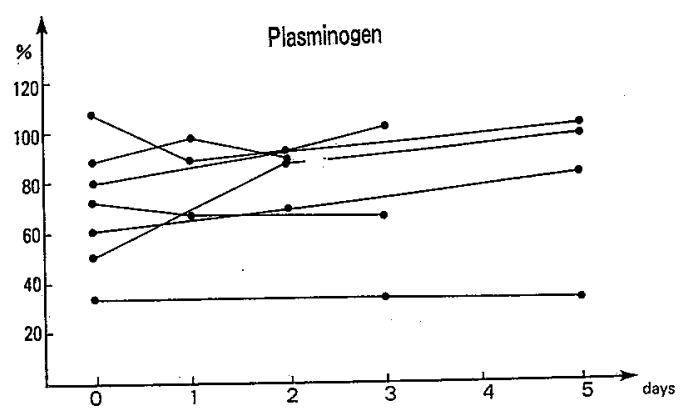

B

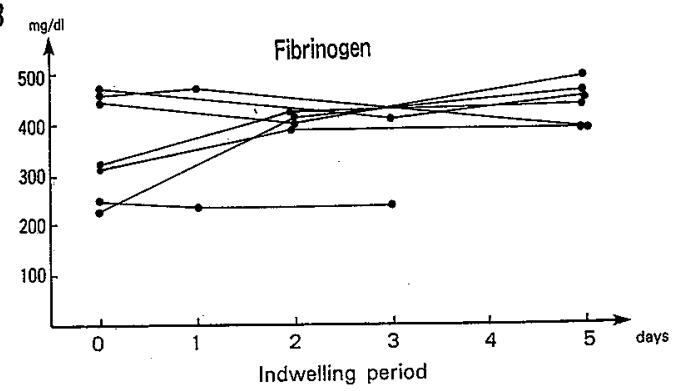

図 3 カテーテル留置中の plasminogen, fibrinogen 血中濃度の変化

あり, 透析前で 4 例の平均は $407.3 \pm 29.6 \mathrm{mg} / \mathrm{d} l$, 後で $400.0 \pm 55.9 \mathrm{mg} / \mathrm{d} l$ であった. このように 3 回の透析で も,フィブリノーゲンにはいずれも有意の変化は認めら れなかった。

図 2 に FPA と FPB $\beta$ の透析前後での血中濃度の変化 を示した.FPA は 1 回目の透析で 1 例で増加, 4 例で減 少した(図 $2 \mathrm{~A}$ )。透析前の 5 例の平均は $18.9 \pm 31.4 \mathrm{ng} /$ $\mathrm{m} l$, 後の平均は $9.7 \pm 18.7 \mathrm{ng} / \mathrm{m} l$ であった. 2 回目の透 析では 2 例で増加， 3 例で減少した. 5 例の平均は透析 前值が $2.3 \pm 1.4 \mathrm{ng} / \mathrm{m} l$, 後值が $3.1 \pm 3.9 \mathrm{ng} / \mathrm{m} l$ であっ た.また 3 回目の透析では, FPA は 1 例で増加, 3 例で 減少した. 4 例の透析前の平均值は $25.9 \pm 27.6 \mathrm{ng} / \mathrm{m} l$, 後 の平均は $2.2 \pm 1.7 \mathrm{ng} / \mathrm{ml}$ であった. 以上 $\mathrm{FPA}$ の透析前 後での変化は 3 回とも有意ではなかった. $\mathrm{FPB} \beta$ の場合 も 1 回目の透析後に 1 例で増加，4例で減少した（図 2 B). 透析前の 5 例の平均値は $52.1 \pm 13.3 \mathrm{ng} / \mathrm{m} l$, 後の平 均值は $45.8 \pm 13.2 \mathrm{ng} / \mathrm{m} l$ であった. 2 回目の透析では 2 例で増加， 3 例で減少した。 5 例の平均值は, 透析前で $46.6 \pm 10.4 \mathrm{ng} / \mathrm{m} l$, 後で $45.9 \pm 16.0 \mathrm{ng} / \mathrm{m} l$ であった. 3 回目の透析では 2 例で増加， 2 例で減少した，4 例の透 析前值の平均は $59.0 \pm 17.4 \mathrm{ng} / \mathrm{m} l$, 後値の平均は $53.0 \pm$ $8.0 \mathrm{ng} / \mathrm{m} l$ で, やはり有意の変動は認められなかった。

図 3 にカテーテル留置中のプラスミノーゲンとフィブ リノーゲンの血中濃度の推移を示した。 3 回目までの透 析前值をプロットした。プラスミノーゲンは，カテーテ

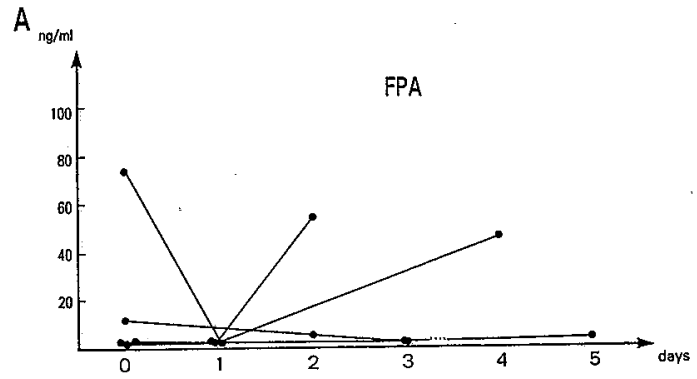

B

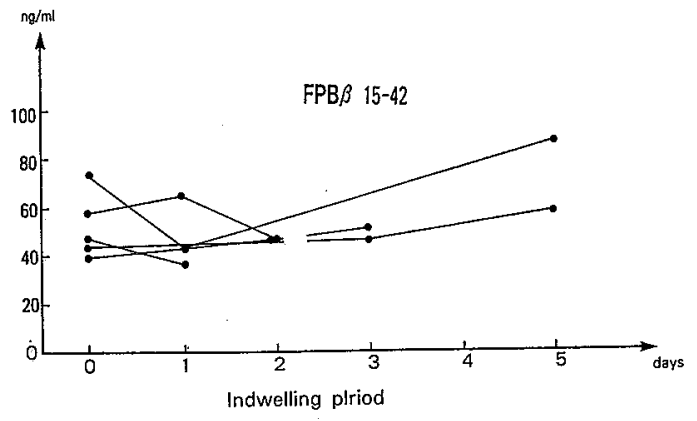

図 4 カテーテル留置中の FPA, FPB $\beta$ 15-42 血 中濃度の変化

ル挿入時に 7 例中 4 例で低值（<75\%）を示した（図 3 A). 3 回目の透析終了時でも2 例で低值であった. 1 例 で明らかな上昇傾向を示したが, 他の 6 例では大 きな変化を示さなかった。カテーテル插入時（1回目の 透析前) の平均が $70.3 \pm 24.5 \%, 3$ 回目の透析前の平均 が $81.3 \pm 25.4 \%$ あった. フィブリノーゲンは, カテー テル挿入時に 3 例で高值 $(>410 \mathrm{mg} / \mathrm{d} l)$ を示したが, 3 回目の透析前にも 3 例で高值であった（図 3 B). 1 例

では $230 \mathrm{mg} / \mathrm{d} l$ も増加したが, 他の 6 例では 100 $\mathrm{mg} / \mathrm{d} l$ 以内の変動に止まった. カテーテル聥入時の平均 值は $355.4 \pm 102.5 \mathrm{mg} / \mathrm{d} l, 3$ 回目の透析前の平均值は $404.1 \pm 83.6 \mathrm{mg} / \mathrm{d} l$ で，両者間に有意の差はなかった。

図 4 にカテーテル留置中の 3 回目の透析までの FPA と $\mathrm{FPB} \beta$ の推移を示した。すなわち FPA は，カテーテ 儿挿入時に 5 例中 4 例で高值 $(>2.0 \mathrm{ng} / \mathrm{m} l)$ を示し, 3 回目の透析前には， 4 例中 3 例が高値を示した(図 4A). 1 例でFPA は一旦減少した後, 再び増加し, 他 の 1 例 で増加したが, 他の 3 例は殆んど変化しな かった。 カテーテル挿入時の FPA 濃度の平均は $18.9 \pm$ $31.4 \mathrm{ng} / \mathrm{m} l, 3$ 回目の透析前が $25.9 \pm 27.6 \mathrm{ng} / \mathrm{m} l$ で, 兩 者の間に有意差はなかった. FPB $\beta$ は，カテーテル挿入 時に全例で高值 $(>4.8 \mathrm{ng} / \mathrm{m} l)$ で, 3 回目の透析前にも 同様に全例が高值を示した(図 $4 \mathrm{~B}$ ). カテーテル留置中 に, 1 例 で一旦減少後に再び増加したが, 他の症 例では大きな変化を示さなかった，カテーテル捜入時の 
A

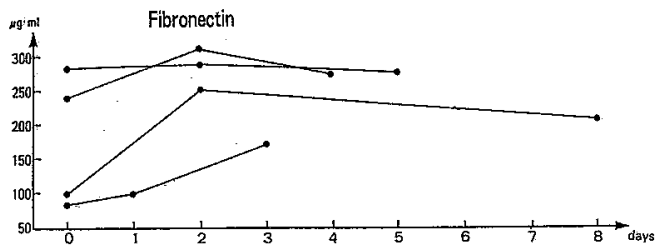

B

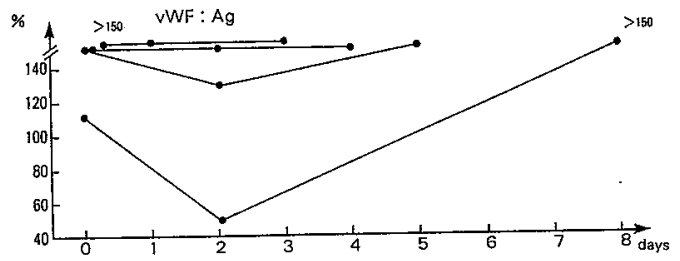

$c$

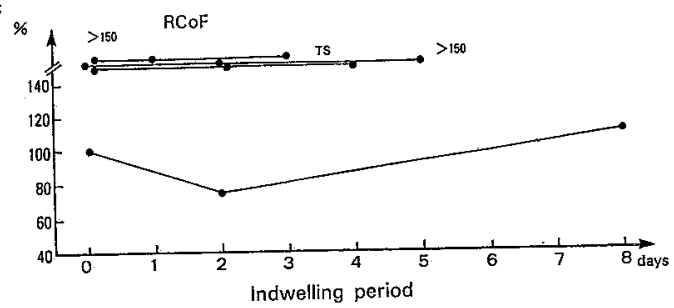

図 5 カテーテル留置中の fibronectin, vWF: Ag, $\mathrm{RCoF}$ 濃度の変化

$\mathrm{FPB} \beta$ の平均值は $52.1 \pm 13.3 \mathrm{ng} / \mathrm{m} l, 3$ 回目の透析前は $59.0 \pm 17.4 \mathrm{ng} / \mathrm{m} l$ で，両者の間に有意差はなかった.

図 5 にフィブロネクチン, vWF : $\mathrm{Ag}$ 拈よび $\mathrm{RCoF}$ の 3 回目までの推移を示した.フィブロネクチンは,カテー テル插入時に 3 例で低值 $(<250 \mu \mathrm{g} / \mathrm{m} l)$ を, 3 回目の透 析前にも 3 例で低值を示した(図 $5 \mathrm{~A}$ ). カカテーテル留置 中に 3 例で増加し，1例で減少した。 カテーテル㨀入時 のフィプロネクチン血中濃度は $177.0 \pm 99.3 \mu \mathrm{g} / \mathrm{m} l, 3$ 回目の透析前の平均は $230.8 \pm 52.0 \mu \mathrm{g} / \mathrm{m} l$ であり, 兩者 の間に有意差はなかった。一方， $\mathrm{vWF}: \mathrm{Ag}$ は，カテー テル㨀入時に 4 例中 3 例で高值 $(>150 \%)$ を示し，3回 目の透析前でも 4 例とも高值であった（図 5 B）。2 例 で一旦減少後に再び増加したが，他の 2 例は 高值を持続した。さらに, $\mathrm{RCoF}$ は, カテーテル挿入時 に 4 例中 3 例で高值 (>150\%) であり，3 回目の透析前 まで高值を持続した（図 $5 \mathrm{C}$ )。他の一例では, $\mathrm{RCoF}$ は一旦減少後に再び増加したが, 常に正常範囲に あった.いずれにせよ, $\mathrm{vWF}: \mathrm{Ag}$ と $\mathrm{RCoF}$ の推移は殆 んど同様であった。

\section{考察}

既に報告した如く，我々が開発した UKFC は，従来 のカテーテルに比べて抗血栓性が高く，かつカデーテル 熱などの合併症の発現頻度も低い ${ }^{5)}$. 抗血栓性の発現機
序としては(1)カテーテル周囲で線溶系が光進する：(2)内 栓充填により血栓形成の場が少なくなる：(3)カテーテル 表面に血小板が粘着しにくい, などが考えられている3 ウロキナーゼによりプラスミノーゲンは分解されプラ スミンを生じ，プラスミンはフィブリンやフィブリノー ゲンを分解して線溶を抗こす。この過程でプラスミノー ゲンとフィブリノーゲンは消費される。 またプラスミン は比較的, 基質特異性が低い蛋白分解酵素であり, フィ ブリノーゲンの他にも in vitroにおいて, 血液凝固第 $\mathrm{V}$, 第VIII，第IX因子を分解することが報告されている ${ }^{8)}$. 力 テーテルに固定化されたウロキナーゼは, 血中で不活化 され，1回の透析施行後に残存活性は数\%にまで低下す る(未発表データ)。したがって，UKFC 留置による線 溶系の変化は, 留置後 1 回目の透析で最も大きいものと 考えた.

今回カテーテルを留置した症例では，プラスミノーゲ ンとフィブリノーゲンは減少しなかった（図 1 , 図 3 ). これらの血漿蛋白は, 多少消費されてもすぐに補充され, 血中濃度は変化しないと考えられるため, FPA と FPB $\beta$ の血中濃度の変化を調べた。 FPA とFPB は, 各々ト口 ンビンとプラスミンにより生成される低分子ペプチド で, 半減期が FPA 51 分, FPB $\beta 135$ 分と短い ${ }^{9)}$. した がって,これらの微量ペプチドの測定により, トロンビ ンとプラスミン活性の変化，すなわち凝固と線溶系の変 化のより適確な把握が可能となる. カテーテル留置後 1 回目の透析では，FPA と FPB $\beta$ の血中濃度は，透析後 に減少する症例が多かった(図 2 )。これは両ぺプチドと も分子量が小さく， dialyzable であるため，血中濃度が 低下した可能性はある。図 4 に示す如くカテーテル留置 中に, 透析前の FPA, FPB $\beta$ 濃度が有意に変化しなかっ た事より，カテーテル留置による凝固線溶系の変化は最 小限に押えられたことが示唆された。

vWF, RCoF はともに高值を持続したが，これは透析 患者における動脈硬化性病変のため, 内:皮細胞からの放 出がふえたためと考えられた ${ }^{10)}$.

UKFC の抗血栓性発現機序の一つに, 血小板の粘着が 少ないことが挙げられている ${ }^{5,7}$. フィブリノーゲン,

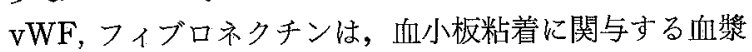
蛋白である ${ }^{11)}$ ，今回の成績では，これらの血獎蛋白がカ テーテル留置中に有意の変化を示さず, カテーテルへの 血小板粘着が，これらの血漿蛋白の低下によるものでは ないと考えられた。

以上より, UKFC 留置による全身の凝固線溶系の変化 は少ないことが示唆された.このことはまた, カテーテ ル留置中に出血傾向の助長を認めないとの従来の報 告4 6)を裏づけるものである。 


\section{結論}

ウロキナーゼ固定化フェモラールカテーテル (UKFC) 留置中の凝固線溶系の変化を, 9 名の維持透析 患者について検討した。 カテーテル留置中にフィブリ ノーゲン，プラスミノーゲン，フィィブリノペプタイド $\mathrm{A}$ ，フィブリノペプタイド $\mathrm{B} \beta$ 15-42 の血中濃度は有意 の変化を示さなかった。 また von Willebrand 因子,フィ ブロネクチンも有意の変化を示さなかった。

以上より UKFC の留置が, 全身の凝固線溶系に及济 す影響は少ないと考えられた。このことは，従来の臨床 評価とともに，このカテーテルの安全性を裏づけるもの である。

本論文要旨の一部は,第 33 回日本透析療法学会にて発表し た。

\section{文献}

1）大城 孟，神前五郎：抗血栓性物質固定化に関する 研究の現況。医学のあゆ $112 ： 367-376,1980$

2) Sugitachi A, Takagi $K$ : Antithrombogenicity of immobilized urokinase-clinical application. Int $\mathrm{J}$ Artif Organs I : 88-92, 1978

3）北本康則, 二木 源, 田熊淑男, 上田 仁, 門間弘 道, 石崎 允, 高橋 寿, 関野 宏, 薮下安紀: ウ ロキナーゼ固定化フェモラールカテーテルの試作と 臨床応用. 医学のあゆみ $135: 329-332,1985$

4）北本康則, 鈴木一之, 二木 源, 田熊淑男, 上田 仁, 門間弘道, 石崎 允, 高橋 寿, 関野 宏, 中道五 郎，妏下安紀：ウロキナーゼ固定化フェモ゙ラールカ テーテル (UKFC) の試作と臨床評価. 人工臟器 $15: 1234-1237,1986$

5) Kitamoto Y, Fukui H, Iwabuchi K, Taguma Y,
Monma H, Ishizaki M, Takahashi H, Nakayama $\mathrm{M}$, Sekino $\mathrm{H}$ : A femoral vein catheter with immobilized urokinase (UKFC) as an antithrombotic blood access. Trans Am Soc Artif Intern Organs $10: 136-139,1987$.

6) 福井博義, 早野惠子, 松下和孝, 中村 靖, 堀川健 太郎, 江上純一, 河津泰祐, 数下安紀：ウロキナー ゼ固定化ブラッドアクセスカテーテルの臨床応用. 腎と透析 $23: 367-372,1987$

7) 北本康則, 菅井久子, 高橋 寿, 薮下安紀, 森 和 夫：ウロキナーゼ固定化材質の抗血栓性発現機序に ついて．血液と脈管 $18 ： 264-266 ， 1987$

8) Henriksson P, Nilsson I M : Effects of leukocytes, plasmin and thrombin on clotting factors. A comparative in vitro study. Thromb Res $16: 301-312$, 1979

9) Lane D A, Marwick J, Thompson E, Ireland, H : Experimental evidence for catabolism of fibrin fragment $\mathrm{B} \beta$ 15-42. Thromb Res $33: 571-581$, 1984

10) Winter M, Needham J, Mackie I, Cameron J S : Impaired vessel wall response to venous occlusion in patients with chronic renal failure on maintainance hemodialysis. Clin Nephrol $22: 307$ $-313,1984$

11) Plow E F, McEver R P, Coller B S, Woods V L Jr, Marguerie G A, Ginsberg M H : Related binding mechanisms for fibrinogen, fibronectin, von Willebrand factor, and thrombospondin on thrombin -stimulated human platelets. Blood $66: 724-727$, 1985 